\title{
Gastric Lipoma
}

National Cancer Institute

\section{Source}

National Cancer Institute. Gastric Lipoma. NCI Thesaurus. Code C5258.

A rare benign adipose tissue neoplasm of the stomach. Clinical presentation includes obstruction and gastrointestinal bleeding. Gastric lipomas occur as solitary lesions most frequently in the antrum. 